\title{
Design of Robust Load Frequency Controller for Multi-Area Interconnected Power System Using SDO Software
}

\author{
Pasala Gopi, P. Linga Reddy \\ Departement of Electrical Engineering, K L University, India
}

\begin{tabular}{|c|c|}
\hline Article Info & ABSTRACT \\
\hline Article history: & The response of the load frequency control problem in multi-area \\
\hline Received Jan 3, 2016 & $\begin{array}{l}\text { interconnected electrical power system is much more complex with } \\
\text { increasing size, changing structure and increasing load. This paper deals }\end{array}$ \\
\hline Revised Feb 10, 2017 & with Load Frequency Control of three area interconnected Power system \\
\hline Accepted Feb 17, 2017 & $\begin{array}{l}\text { incorporating Reheat, Non-reheat and Reheat turbines in all areas } \\
\text { respectively. The response of the load frequency control problem in a multi- }\end{array}$ \\
\hline Keyword: & $\begin{array}{l}\text { area interconnected power system is improved by designing PID controller } \\
\text { using different tuning techniques and proved that the PID controller which }\end{array}$ \\
\hline Interconnected Power system & was designed by Simulink Design Optimization (SDO) Software gives the \\
\hline Load Frequency Control & superior performance than other controllers for step perturbations. Finally the \\
\hline PID Tuning Techniques & robustness of controller was checked against system parameter variations.. \\
\hline Robust Controller & \\
\hline Tie Line Power & $\begin{array}{r}\text { Copyright } \odot 2017 \text { Institute of Advanced Engineering and Science. } \\
\text { All rights reserved. }\end{array}$ \\
\hline \multicolumn{2}{|l|}{ Corresponding Author: } \\
\hline \multicolumn{2}{|l|}{ Pasala Gopi, } \\
\hline \multicolumn{2}{|l|}{ Research Scholar, } \\
\hline \multicolumn{2}{|c|}{ Departement of Electrical Engineering, } \\
\hline \multicolumn{2}{|l|}{ K L University, } \\
\hline \multicolumn{2}{|c|}{ Grean Fields, Vaddeswaram, Vijayawada, Guntur (Dist), A.P., India. } \\
\hline
\end{tabular}

\section{INTRODUCTION}

For large scale power systems which consists of interconnected control areas, load frequency then it is important to keep the frequency and inter area tie power near to the scheduled values. The input mechanical power is used to control the frequency of the generators and the change in the frequency and tieline power are sensed, which is a measure of the change in rotor angle. A well designed power system should be able to provide the acceptable levels of power quality by keeping the frequency and voltage magnitude within tolerable limits. Changes in the power system load affect mainly the system frequency, while the reactive power is less sensitive to changes in frequency and is mainly dependent on fluctuations of voltage magnitude. The AGC or LFC system solely cannot control the disturbances, it need another controller like Integral (I) or Proportional plus Integral (PI), Proportional plus Integral plus Derivative (PID) controller.

\subsection{Over on Load Frequency Control Schemes}

Automatic generation control (AGC) can be defined as, the regulation of power output of controllable generators within a prescribed area in response to change in system frequency, tie-line loading, or a relation of these to each other, to maintain the scheduled system frequency and/or the established interchange with other areas within predetermined limits (Elgerd, 2001). Therefore, a control strategy is needed that not only maintains constancy of frequency and desired tie-power flow but also achieves zero steady state error and inadvertent interchange. Although there is a heap of research papers available in the literature relating AGC problem of power systems. They dealt various aspects of AGC schemes demonstrating the superiority of one scheme over the others. However, there are few notable contributions of the early stages of AGC, which have set the landmarks in the development of AGC schemes [5]. 
The first attempt in the area of AGC has been to control the frequency of a power system via the governor of the synchronous machine, but this technique was found to be insufficient and requires a supplementary control for the governor with the help of a signal which is directly proportional to the frequency deviation plus it's integral. This scheme constitutes the classical approach to the AGC of power systems. Cohn has done very early works in this important area of AGC. Concordia et al and Cohn have presented basic important works on tie-line power and frequency control and tie line bias control in interconnected systems $[1,4]$.

The Current Operational Problems working group has discussed the problems and requirements of the regulation of generation on interconnected power systems in short notes namely, Regulation requirement imposed on operators beyond the considerations of long term planners and Regulation performance criteria, Operating problems of system regulation and factors influencing interconnected operations. Among the various types of load frequency controllers, the most commonly used one is conventional Proportional Integral (PI) controller. The PI controller is very simple for construction, implementation and gives better dynamic response, but their performance is unsatisfied when the complexity of the system increases due to load disturbances or load variations. Today's power systems are more complex and require operation in uncertain less structured environment. Consequently, secure, economic and stable operation of a power system requires improved and innovative methods of control. Optimal control techniques provide a high adaption to changing conditions and have ability to make decisions quickly by processing imprecise information. Some of these techniques are ZN-Pessen Integral Rule, Integral Square Error (ISE) and Simulink Design Optimization (SDO) Software etc.

\subsection{Over on Power System Models}

In Feb'84, the UEA began implementation of a test to identify the improvement to electric system automatic generation and tie line control that could be achieved by the application of variable, non-linear tie line frequency bias. The test showed that when tie line frequency bias is better matched to system response, the result would be that, the area control error performance would be improved and generating unit regulation would be reduced. In addition the interconnection reliability was enhanced. This work has been discussed by T. Kennedy et al. K.C. Divya have discussed the simulation model of two area hydro-hydro interconnected system and they showed that the difficulty in extending the traditional approach. They prepared the model by ignoring the frequency deviations between the control areas. Engin Yesil, Aysen Demiroren, Erkin Yesil have presented a three area power with two reheat turbine type thermal units and a hydro unit as shown in Figure 1. Here the non-linear (dead-band effects) state space equations of the power system are used directly during the control of the system by FLC and by conventional proportional integral controller [1]. So far, many authors were discussed dynamic responses of interconnected power system for step load perturbations only, this paper deals with dynamic responses of interconnected power system for random load perturbations.

\section{MATHEMATICAL MODELING OF POWER SYSTEM}

The main difference between Load Frequency Control of multi-area system and that of single area system is, the frequency of each area of multi-area system should return to its nominal value and also the net interchange through the tie-line should return to the scheduled values. So a composite measure, called area control error (ACE), is used as the feedback variable. A decentralized controller can be tuned assuming that there is no tie-line exchange power, $\mathrm{P}_{\text {tiei }}=0$. In this case the local feedback control will be $u i=-\mathrm{K}_{i}(s) \mathrm{B}_{\mathrm{i}} \Delta f_{i}$. Thus load frequency controller for each area can be tuned independently. To illustrate the decentralized PID tuning method, consider a Three-Area power system as shown in Figure 1.

Figure 2 shows a Three-area interconnected system block diagram with load perturbations. The system frequency deviation $\Delta f_{i}$, the deviation in the tie-line power flow $\Delta \mathrm{P}_{\text {tiei }}$, load disturbance $\Delta \mathrm{P}_{\mathrm{Li}}$. The system parameter values are given in Appendix. The system state-space model can be represented as [8, 9].

$$
\dot{\mathrm{X}}=\mathrm{A} x+\mathrm{B} u \text { and } \quad \mathrm{Y}=\mathrm{C} x
$$
State matrix.

Where $\mathrm{A}$ is system matrix, $\mathrm{B}$ is input matrix; $u$ is control matrix; $\mathrm{Y}=$ output matrix and $x$ is

\subsection{Mathematical Modeling of Power Generating Units}

In power systems, a turbine unit is used to transform the natural energy (like energy from steam or water) into mechanical power $\left(\Delta P_{m}\right)$ that is supplied to the generator. In LFC model, there are three different types of commonly used turbines; those are Non-Reheat, Reheat \& hydraulic turbines, all of which can be modeled by transfer functions [1]. 
Non-reheat turbines are first-order units. A time delay $\left(T_{t}\right)$ occurs between switching the valve and producing the turbine torque. The transfer function can be of the non-reheat turbine is represented as

$$
G_{N r}(s)=\frac{1}{(1+s T t)}=\frac{N U M t(s)}{\operatorname{DENt}(s)}
$$

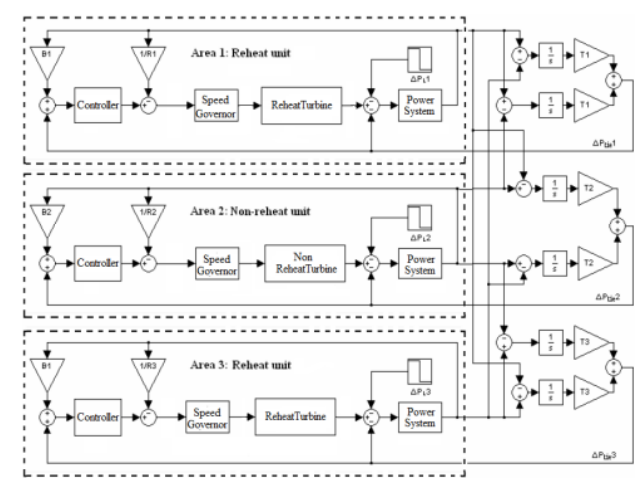

Figure 1. Three Area Interconnected Power System with Step Load Perturbations

Because of different stages due to high and low steam pressure in the Reheat turbines, it was modeled as second-order units. The transfer function of reheat turbine can be represented as

$$
\operatorname{Gr}(s)=\frac{1+\mathrm{sCTtr}}{(1+\mathrm{sTtr})(1+\mathrm{sTlpr})}=\frac{\operatorname{NUMt}(\mathrm{s})}{\operatorname{DENt}(\mathrm{s})}
$$

Where $T_{l p r}$ is the low pressure reheat time and $C$ represents the high pressure stage rating, $T_{t r}$ is the reheat turbine time constant.

The Speed Governors are used in power systems to sense the frequency variations $(\Delta \mathrm{f})$ which are caused by the load change $\left(\Delta \mathrm{P}_{\mathrm{L}}\right)$ and are cancelled by varying the turbine inputs. The block diagram representation of a speed governing system is shown in Figure 2, where $R$ is the speed regulation and $T_{s g}$ is the time constant of the Speed Governor [6]. Suppose if there is no load reference and there are load changes occurs, some part of the change may be compensated by the valve or gate settings and the remaining of the change is represented in the form of frequency variations. The goal of Load Frequency Control (LFC) is to compensate the frequency deviations due active power load variations. Thus, the load reference set-point can be used to adjust the valve/gate positions so that all the load change is canceled by the power generation rather than resulting in a frequency deviation as shown in Figure 2. The transfer function can be represented as.

$$
\operatorname{Gsg}(s)=\frac{1}{(1+s T s g)}=\frac{\text { NUMsg(s) }}{\text { DENsg(s) }}
$$

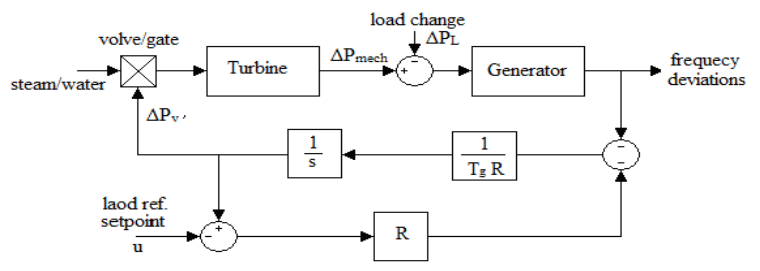

Figure 2. Block Diagram Representation of Speed Governorning Unit

A generator converts the mechanical power developed by the turbine into electrical power. Because of difficulty of storage of electrical power in large amounts, the balance has to be maintained between the generated power and the load demand to maintain the system stability. Once the load variations occurs, the mechanical power $\left(P_{\text {mech }}\right)$ from the turbine will not match the electrical power $\left(P_{\text {ele }}\right)$ generated by the 
generator. The error between the mechanical $\left(\Delta P_{\text {mech }}\right)$ and electrical powers $\left(\Delta P_{\text {ele }}\right)$ is integrated into the rotor speed deviation $\left(\Delta \omega_{r}\right)$, which can be converted into the frequency variations $(\Delta f)$ by multiplying with $2 \pi$. The following figure shows the block diagram of generator with load damping (D) effect.

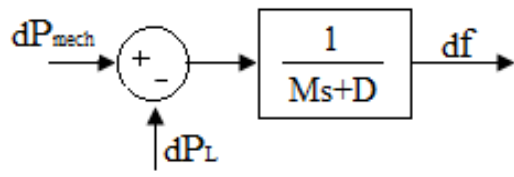

Figure 3. Block Diagram of Generator with Load Damping Effect

The Laplace transform of generator with load damping is

$$
\begin{aligned}
& \Delta \mathrm{P}_{\text {mech }}(\mathrm{s})-\Delta \mathrm{P}_{\mathrm{L}}(\mathrm{s})=(\mathrm{Ms}+\mathrm{D}) \Delta \mathrm{F}(\mathrm{s}) \\
& \mathrm{G}_{\mathrm{ps}}(\mathrm{s})=\frac{1}{(\mathrm{D}+\mathrm{Ms})}=\frac{\mathrm{K}_{\mathrm{ps}}}{\left(1+\mathrm{sT}_{\mathrm{ps}}\right)}=\frac{\operatorname{NUMg}_{\mathrm{g}}(\mathrm{s})}{\mathrm{DEN}_{\mathrm{g}}(\mathrm{s})}
\end{aligned}
$$

In an interconnected power system, different areas are connected with each other with the help of tie-lines. When the frequency variations in two areas are different, a power exchange occurs through the tieline between the connected two areas. The block diagram representation of tie-line is as shown in Figure 3.

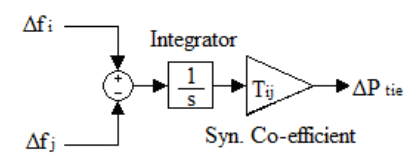

Figure 4. Block Diagram Representation of Tie-line Connections

The Laplace transform of tie line in Figure 4 is given by

$$
\Delta P_{\text {tieij }}(s)=\frac{T_{i j}\left(\Delta F_{i}(s)-\Delta F_{j}(s)\right)}{s}
$$

Where $\Delta P_{t i e i j}$ is tie line power exchange between areas $i$ and $j$, and $T_{i j}$ is the tie-line synchronizing coefficient between area $i$ and $j[6]$.

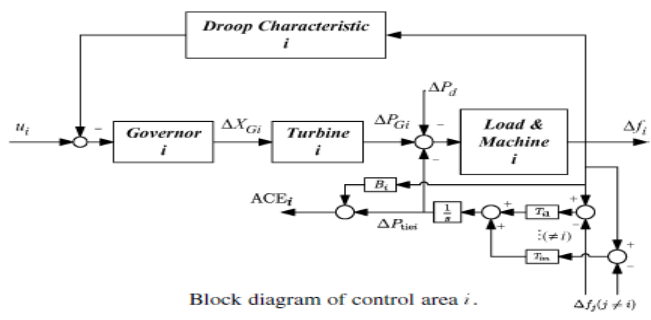

Figure 5. Block Diagram of Control Area i

The goal of Load Frequency Control is not only to compensate the frequency error in each area, but also to control the tie-line power exchange according to schedule [6]. Because the tie-line power error is the integral of the frequency difference between each pair of areas, if we control frequency error to zero, any steady state errors in the frequency of the system would result in tie-line power errors. Therefore we need to include the information of the tie-line power deviation into our control input. As a result, an area control error (ACE) is defined as (referred to figure 5) 


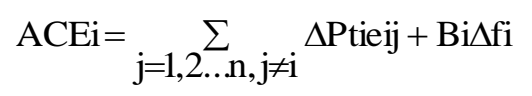

Where $B_{i}$ is the frequency bias constant for area $i$ and $\quad \mathrm{B}_{\mathrm{i}}=1 / \mathrm{R}_{\mathrm{i}}+\mathrm{D}_{\mathrm{i}}$. This ACE signal is used as the plant output of each power generating area [6].

\subsection{Mathematical Modeling of Power System Areas}

Let area 1, 2, 3 are non identical systems with Reheat, Non-reheat and Reheat turbines in all three areas respectively. The transfer function of each area with generator drooping characteristics can be defined as

$$
\mathrm{G}_{\mathrm{p}}(\mathrm{s})=\frac{\operatorname{Gsgi}(\mathrm{s}) \mathrm{Gti}(\mathrm{s}) \mathrm{Gpsi}(\mathrm{s}) \mathrm{Bi}}{1+\operatorname{Gsgi}(\mathrm{s}) \mathrm{Gti}(\mathrm{s}) \operatorname{Gpsi}(\mathrm{s}) / \operatorname{Ri}}=\frac{\operatorname{NUMsg}(\mathrm{s}) \operatorname{NUMt}(\mathrm{s}) \operatorname{NUMps}(\mathrm{s}) \operatorname{Bi}}{\operatorname{DENsg}(\mathrm{s}) \operatorname{DENt}(\mathrm{s}) \operatorname{DENps}(\mathrm{s})+\operatorname{NUMsg}(\mathrm{s}) \operatorname{NUMt}(\mathrm{s}) \operatorname{NUMps}(\mathrm{s}) / \mathrm{K}}
$$

The transfer functions of all three areas of interconnected power system are as follows (see appendix for Turbine, Speed Governor and Power system parameters):

For Area-1, the transfer function is

$$
\mathrm{G}_{1}(\mathrm{~s})=\frac{1 *(3 \mathrm{~s}+1) * 115 * 0.5087}{(1+0.08 \mathrm{~s})\left(1+10.3 \mathrm{~s}+3 \mathrm{~s}^{2}\right)(1+15 \mathrm{~s})+1 *(3 \mathrm{~s}+1) * 115 / 2}=\frac{48.75 \mathrm{~s}+16.25}{\mathrm{~s}^{4}+16 \mathrm{~s}^{3}+44.312 \mathrm{~s}^{2}+55 \mathrm{~s}+16.25}
$$

For Area-2, the transfer function is

$$
\mathrm{G}_{2}(\mathrm{~s})=\frac{1 * 1 * 120}{(1+0.08 \mathrm{~s})(1+0.3 \mathrm{~s})(1+20 \mathrm{~s})+1 * 1 * 120 / 2.4} 0.425=\frac{106.25}{\mathrm{~s}^{3}+15.88 \mathrm{~s}^{2}+42.46 \mathrm{~s}+106.25}
$$

For Area-3, the transfer function is

$$
\mathrm{G}_{3}(\mathrm{~s})=\frac{1 *(5 \mathrm{~s}+1) * 120 * 0.425}{(1+0.08 \mathrm{~s})\left(1+10.3 \mathrm{~s}+3 \mathrm{~s}^{2}\right)(1+20 \mathrm{~s})+1 *(5 \mathrm{~s}+1) * 120 / 2}=\frac{53.125 \mathrm{~s}+10.625}{\mathrm{~s}^{4}+15.98 \mathrm{~s}^{3}+44.05 \mathrm{~s}^{2}+58.41 \mathrm{~s}+10.625}
$$

\section{TUNING OF LOAD FREQUENCY CONTROLLER}

For industrial plant process, the conventional PID controllers are most commonly used. They are doing some challenges to control, instrumentation and power engineers in the area of tuning of the gains of controllers required for best transient performance and stability. There are several prescriptive rules used for tuning of PID controller [3]. The parallel form of a PID controller has transfer function:

$$
\mathrm{Gc}(\mathrm{s})=\mathrm{Kp}+\frac{\mathrm{Ki}}{\mathrm{s}}+\mathrm{sKd}=\mathrm{Kp}\left(1+\frac{1}{\mathrm{sTi}}+\mathrm{sTd}\right)
$$

$K_{p}=$ Proportional Gain constant; $K_{i}=$ Integral Gain constant; $T_{i}=$ Reset Time constant $=K_{p} / K_{i}, K_{d}=$ Derivative gain constant; $T_{d}=$ Rate time or derivative time constant.

The tuning of PID load frequency controller of multi-area power system that it has to bring frequency of each area to its nominal value and also the change in tie-line power should return to the scheduled values. So the combination of both, called Area Control Error (ACE), is used as feedback variable. For area-i, the ACE is defined as $A C E_{i}=\Delta P_{\text {tiei }}+B_{i} \Delta f_{i}$ and Feedback control signal for area-i is $u_{i}=-K_{i}(s)$ $\mathrm{AEC}_{\mathrm{i}}$. A PID load frequency controller can be tuned assuming that there is no tie line power exchange i.e $\Delta \mathrm{P}_{\text {tiei }}=0$. Now the feedback control signal $\mathrm{u}_{\mathrm{i}}=-\mathrm{K}_{\mathrm{i}}(\mathrm{s}) \mathrm{B}_{\mathrm{i}} \Delta \mathrm{f}_{\mathrm{i}}$

\subsection{Ziegler-Nichols (Z-N) Method}

Recently a new tuning rule for PID controller was prepared by Ziegler-Nichols called Pessen Integral Rule (PIR). The procedure for tuning a PID controller using Pessen Integral Rule (PIR) is similar to $2^{\text {nd }}$ method of Ziegler-Nichols PID tuning [7].

The steps for tuning a PID controller using Pessen Integral Rule:

1. Reduce the integrator and derivative gains to 0 . 
2. Increase proportional gain $\mathrm{Kp}$ value from 0 to some critical value at which sustained oscillations occur.

3. Note the value $\mathrm{Kcr}$ and the corresponding time period of sustained oscillations, Pcr. Now the controller gains can be evaluated as follows

\begin{tabular}{cccc}
\hline \multirow{2}{*}{ Z-N Tuning } & \multicolumn{3}{c}{ P I D Constants } \\
& $\mathrm{K}_{\mathrm{P}}$ & $\mathrm{K}_{\mathrm{I}}$ & $\mathrm{K}_{\mathrm{D}}$ \\
\hline Pessen Integral Rule & $0.7 \mathrm{~K}_{\mathrm{cr}}$ & $2.5 \mathrm{~K}_{\mathrm{p}} / \mathrm{P}_{\mathrm{cr}}$ & $3 \mathrm{~K}_{\mathrm{P}}\left(\mathrm{P}_{\mathrm{cr}} / 20\right)$ \\
\hline
\end{tabular}

The $\mathrm{K}_{\mathrm{P}}, \mathrm{K}_{\mathrm{I}}$ and $\mathrm{K}_{\mathrm{D}}$ values of PID controller for all three areas using Ziegler-Nichols Pessen Integral Rule (PIR) are:

\begin{tabular}{cccc}
\hline & \multicolumn{3}{c}{ Pessen Integral Rule } \\
Area-i & $\mathrm{K}_{\mathrm{P}}$ & $\mathrm{K}_{\mathrm{I}}$ & $\mathrm{K}_{\mathrm{D}}$ \\
\cline { 2 - 4 } Area-I & 8.1795 & 20.4487 & 1.2269 \\
Area-II & 3.7429 & 9.3572 & 0.5614 \\
Area-III & 7.8414 & 19.6035 & 1.1762 \\
\hline
\end{tabular}

\subsection{Automatic PID Tuner}

To tune PID controller of single loop control system having PID automatically, use Simulink control design PID Tuner. With PID tuner it is possible to achieve good balance between performance and robustness. The procedure for automatic PID tuning is as follows:

1. Create a Simulink model with a PID controller for any order and any time delay in MATLAB/Simulink.

2. Double click on PID controller block to open the PID controller dialog box.

3. In dialog box click 'Tune', it automatically linearizes the plant and designs an initial controller.

The $K_{P}, K_{I}$ and $K_{D}$ values of PID controller for all three areas using Automatic PID Tuner are

\begin{tabular}{cccc}
\hline \multirow{2}{*}{ Area-i } & \multicolumn{3}{c}{ Automatic PID Tuner } \\
& $\mathrm{K}_{\mathrm{P}}$ & $\mathrm{K}_{\mathrm{I}}$ & $\mathrm{K}_{\mathrm{D}}$ \\
\cline { 2 - 4 } Area-I & 5.7166 & 4.7307 & 1.7216 \\
Area-II & 1.2954 & 1.8696 & 0.2225 \\
Area-III & 5.2724 & 4.6325 & 1.4896 \\
\hline
\end{tabular}

\subsection{Integral Square Error (ISE) Optimization}

A measure of system performance formed by integrating the square of the system error over a fixed interval of time; this performance measure and its generalizations are frequently used in linear optimal control and estimation theory. The transfer function for PID Controllers of different areas in interconnected power system with Integral Square Error (ISE) Optimization technique are given as

For Area-I:

$$
\mathrm{G}_{\mathrm{c}}(\mathrm{s})=6.4506+\frac{4.9620}{\mathrm{~s}}+4.8627 \mathrm{~s}
$$

For Area-II:

$$
\mathrm{G}_{\mathrm{c}}(\mathrm{s})=6.9775+\frac{4.9839}{\mathrm{~s}}+4.9839 \mathrm{~s}
$$

For Area-III:

$$
\mathrm{G}_{\mathrm{c}}(\mathrm{s})=7.4557+\frac{4.9705}{\mathrm{~s}}+4.8711 \mathrm{~s}
$$

In this paper, the transfer function for PID Controller with Integral Square Error Optimization technique was obtained by SISO tool in MATLAB/Simulink. 


\subsection{Simulation Design Optimization (SDO) Software}

The Signal Constraint block is connected in developed MATLAB/Simulink model to optimize the model response for known inputs. The symbol of Signal Constraint block is as shown below:

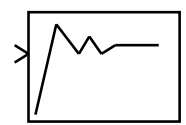

Figure 6. Signal Constraint

To get optimized parameters of a Simulink model, the following steps have to follow:

1. Develop and open the simulink model.

2. Open the simulink design optimization block by typing sdolib at MATLAB command prompt.

3. Drag and drop the signal constraint block in the developed MATLAB/Simulink model.

4. Connect the signal constraint block to signal to which you want toget specified design requirments.

The transfer function for PID Controllers of different areas in interconnected power system having different turbine units in each area with Simulink Design Optimization Software are given as

For Area-I:

$$
\mathrm{G}_{\mathrm{c}}(\mathrm{s})=2.9626+\frac{1.8214}{\mathrm{~s}}+5.3726 \mathrm{~s}
$$

For Area-II:

$$
\mathrm{G}_{\mathrm{c}}(\mathrm{s})=1.3383+\frac{3.0743}{\mathrm{~s}}+0.3381 \mathrm{~s}
$$

For Area-III:

$$
\mathrm{G}_{\mathrm{c}}(\mathrm{s})=14.3220+\frac{5.5195}{\mathrm{~s}}+4.6921 \mathrm{~s}
$$

To design the controllers for interconnected power system using SDO Software, it requires Simulink Design Optimization toolbox.

\section{SIMULATION AND RESULT ANALYSIS}

Let Areas 1, 2, and 3 are non identical i.e all areas of interconnected Power system incorporating Reheat, Non-reheat and Reheat turbines respectively. The parameters of all three areas are collected from various steam power stations in India and are shown in appendix-I.

To estimate the performance of the decentralized PID controller, a step load of $d P_{L 1}=0.01 \mathrm{pu}, d P_{L 2}$ $=0.02 \mathrm{pu}$ and $d P_{L 3}=0.015 \mathrm{pu}$ is applied to Area-I, Area-II and Area-III respectively at $\mathrm{t}=0$ sec.

\subsection{Case-I: Nominal values of system parameters}

The responses of Frequency variations $(\mathrm{pu})$ and Tie line power variations $(\mathrm{pu})$ of the system are shown in Figs. 7 and 8 for nominal values of system parameters.

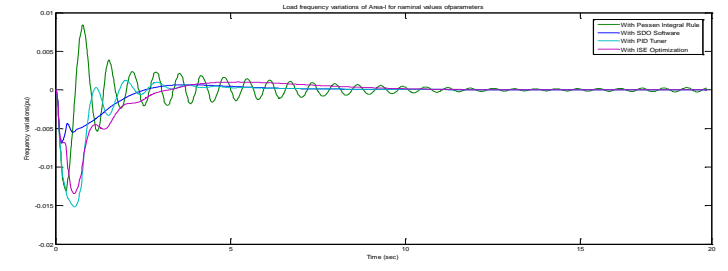

(a) Area-I Frequency Variations $\left(\mathrm{df}_{1}\right)$

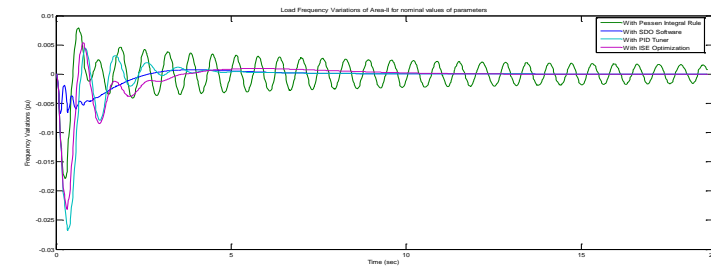

(b) Area-II Frequency Variations $\left(\mathrm{df}_{2}\right)$ 


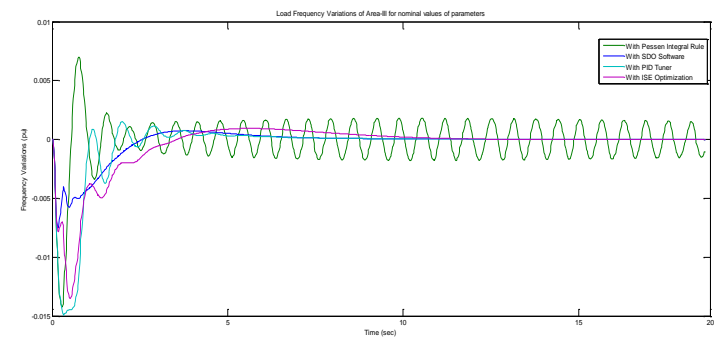

(c) Area-III Frequency Variations $\left(\mathrm{df}_{3}\right)$

Figure 7. Frequency Deviations Of Three Area Interconnected Power System

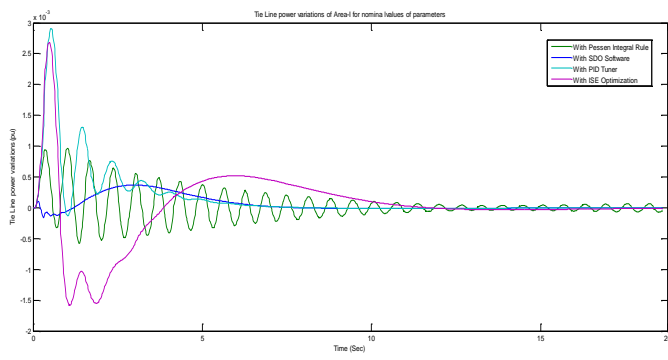

(a) Area-I Tie Line Power variations $\left(\mathrm{dP}_{\text {tiel }}\right)$

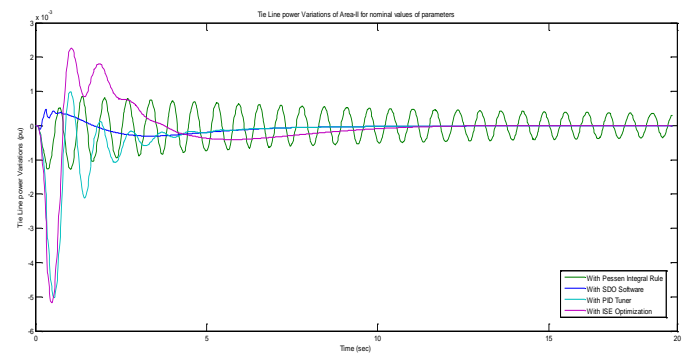

(b) Area-II Tie Line Power variations $\left(\mathrm{dP}_{\text {tie } 2}\right)$

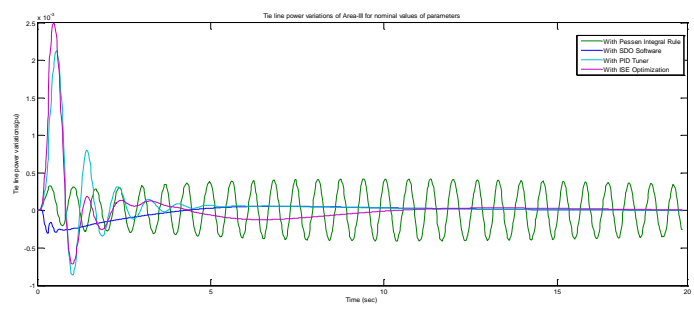

(c) Area-III Tie Line Power variations $\left(\mathrm{dP}_{\text {tie3 }}\right)$

Figure 8: Tie Line Power Deviations of Three Area Interconnected Power System

In this paper, the robustness of the designed PID controllers are checked for $\pm 10 \%$ variations of system parameters (see appendix-I). For $\pm 10 \%$ variations of system parameters, the PID controller which was designed by Z-N Pessen Integral Rule makes the system unstable

\subsection{Case-II: $+10 \%$ Variations in Nominal values of system parameters}

The figures 11 and 12 show responses of Frequency variations (pu) and Tie line power variations (pu) of the system for $-10 \%$ variations of nominal values of system parameters with a step load of $d P_{L 1}=$ $0.01 \mathrm{pu}, d P_{L 2}=0.02 \mathrm{pu}$ and $d P_{L 3}=0.015 \mathrm{pu}$ is applied to Area-I, Area-II and Area-III respectively at $\mathrm{t}=0$ sec.

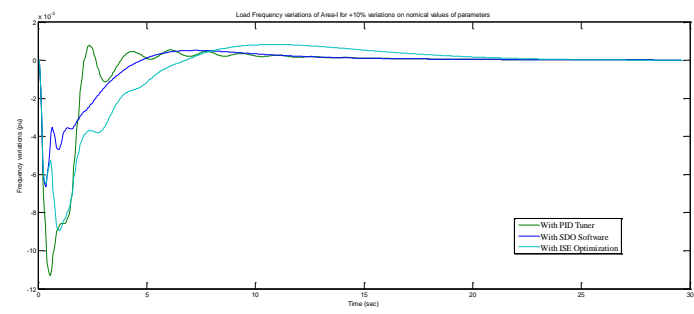

(a) Area-I Frequency Variations $\left(\mathrm{df}_{1}\right)$

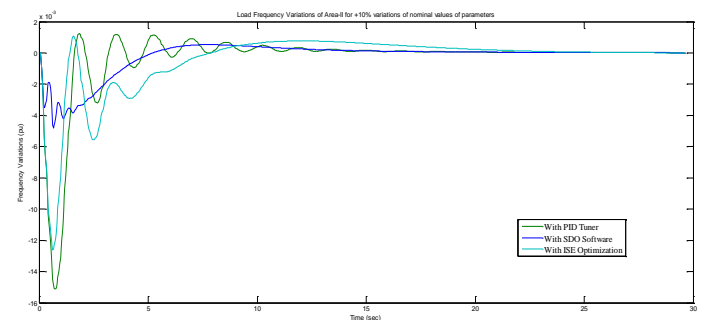

(b) Area-II Frequency Variations $\left(\mathrm{df}_{2}\right)$ 


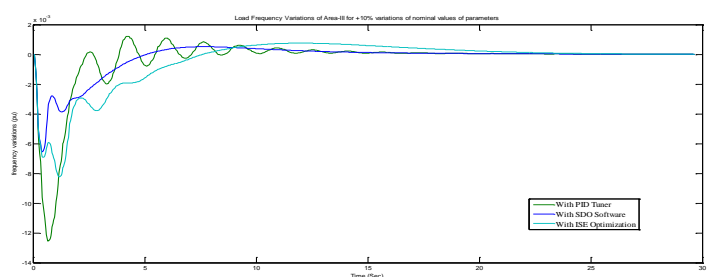

(c) Area-III Frequency Variations $\left(\mathrm{df}_{3}\right)$

Figure 9: Frequency Deviations of Three Area Interconnected Power System

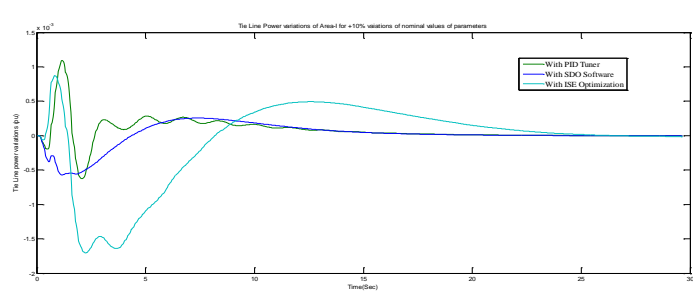

(a) Area-I Tie Line Power variations $\left(\mathrm{dP}_{\text {tiel }}\right)$

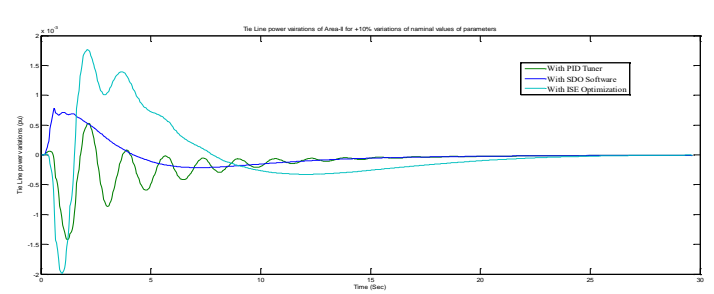

(b) Area-II Tie Line Power variations $\left(\mathrm{dP}_{\text {tie2 }}\right)$

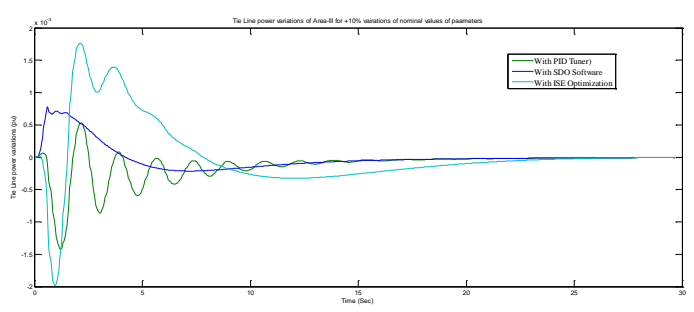

(c) Area-III Tie Line Power Variations $\left(\mathrm{dP}_{\text {tie3 }}\right)$

Figure 10: Tie Line Power Deviations of Three Area Interconnected Power System

\subsection{Robustness of Controller}

From the observation of all above simulation results, the dynamic performance and the robustness of PID controller designed by SDO software is better than all other PID controller for step load perturbations. The Z-N PIR tuned PID controller fails to stable the system for $\pm 10 \%$ variations of nominal values of system parameters. Also the PID controller designed by SDO software gives the better result the PID tuner. The simulation results are summarized in table-1, 2 and 3 for $\pm 10 \%$ variations of nominal values of system parameters and with a step load at $\mathrm{t}=0$ sec.

Table 1: Nominal Values of Parameters

\begin{tabular}{|c|c|c|c|c|c|c|c|c|c|}
\hline \multirow[b]{2}{*}{$\begin{array}{l}\text { PID Tuning } \\
\text { Methods }\end{array}$} & \multicolumn{3}{|c|}{$\begin{array}{c}\text { ArearI } \\
\text { (Reheat Turbine) }\end{array}$} & \multicolumn{3}{|c|}{$\begin{array}{c}\text { Arer-II } \\
\text { (Non-Reheat Turbine) }\end{array}$} & \multicolumn{3}{|c|}{$\begin{array}{c}\text { Arer-II } \\
\text { (Reheat Turbine) }\end{array}$} \\
\hline & 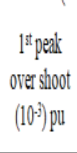 & $\begin{array}{c}\text { Settle } \\
\text { Time(sec) }\end{array}$ & $\begin{array}{c}\text { Steady } \\
\text { State } \\
\text { Emor( } \\
\text { pul })\end{array}$ & $\begin{array}{c}1^{\text {st peak }} \\
\text { over } \\
\text { shoot(10- } \\
\text { 3) pul }\end{array}$ & $\begin{array}{l}\text { Settle } \\
\text { Time(s } \\
\text { ec) }\end{array}$ & $\begin{array}{c}\text { Steady } \\
\text { State } \\
\text { Emoror(pu) }\end{array}$ & 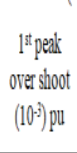 & $\begin{array}{l}\text { Settle } \\
\text { Time(s } \\
\text { ec) }\end{array}$ & $\begin{array}{l}\text { Steady } \\
\text { State } \\
\text { Error(pul) }\end{array}$ \\
\hline Z:NPR & \multicolumn{3}{|c|}{ Becomes unstable } & \multicolumn{3}{|c|}{ Becomes unstable } & \multicolumn{3}{|c|}{ Becomes unstable } \\
\hline $\begin{array}{l}\text { PD Tuner } \\
\text { ISE }\end{array}$ & +0.47 & 22.8 & 0 & $\cdot 14.9$ & 13.7 & 0 & $\cdot 12.6$ & 12.4 & 0 \\
\hline Optimizatio & +1.27 & 32.2 & 0 & $\cdot 12.4$ & 15 & 0 & .6 .86 & 15.2 & 0 \\
\hline $\begin{array}{l}\text { SDO } \\
\text { Software }\end{array}$ & $: 44$ & 22.2 & 0 & -3.4 & 11.5 & 0 & .6 .5 & 14.8 & 0 \\
\hline
\end{tabular}

Table 2: $+10 \%$ Variations of Nominal Values of

\begin{tabular}{|c|c|c|c|c|c|c|c|c|c|}
\hline \multicolumn{10}{|c|}{ Parameters } \\
\hline & \multicolumn{3}{|c|}{$\begin{array}{c}\text { Area:I } \\
\text { (Reheat Turbine) }\end{array}$} & \multicolumn{3}{|c|}{$\begin{array}{c}\text { Arer-I } \\
\text { (Non-Reheat Turbine) }\end{array}$} & \multicolumn{3}{|c|}{$\begin{array}{c}\text { Area-II } \\
\text { (Reheat Turbine) }\end{array}$} \\
\hline $\begin{array}{l}\text { PDD Tuning } \\
\text { Methods }\end{array}$ & $\begin{array}{c}1^{\text {tt peak over }} \\
\text { shoot }\left(10^{-3}\right) \\
\text { pu }\end{array}$ & $\begin{array}{l}\text { Settle } \\
\text { Time(s } \\
\text { ec) }\end{array}$ & $\begin{array}{c}\text { Stea } \\
\text { dy } \\
\text { State } \\
\text { Error } \\
\text { (pu) }\end{array}$ & $\begin{array}{c}1^{\mathbb{t} \text { peak orer }} \\
\text { shoot }\left(10^{-3}\right) \\
\mathrm{pu}\end{array}$ & $\begin{array}{l}\text { Settle } \\
\text { Time } \\
\text { (sec) }\end{array}$ & $\begin{array}{l}\text { Stendy } \\
\text { State } \\
\text { Error(pu) }\end{array}$ & $\begin{array}{c}1^{\text {tt peak }} \\
\text { over shoot } \\
\left(10^{-3}\right) \text { pu }\end{array}$ & $\begin{array}{c}\text { Settle } \\
\text { Time(s } \\
\text { ec) }\end{array}$ & $\begin{array}{c}\text { Steady } \\
\text { State } \\
\text { Errorf(pu) }\end{array}$ \\
\hline Z:NPR & \multicolumn{3}{|c|}{ Becomes unstable } & \multicolumn{3}{|c|}{ Becomes unstable } & \multicolumn{3}{|c|}{ Becomes unstable } \\
\hline $\begin{array}{l}\text { PD Tuner } \\
\text { ISE }\end{array}$ & $\cdot 11.3$ & 21.48 & 0 & $\cdot 15.1$ & 20.15 & 0 & $\cdot 12.5$ & 22.15 & 0 \\
\hline $\begin{array}{c}\text { Optimizatio } \\
\mathbb{1}\end{array}$ & -6.45 & 27.7 & 0 & $\cdot 12.6$ & 24.04 & 0 & -6.9 & 24.5 & 0 \\
\hline $\begin{array}{l}\text { SDO } \\
\text { Software }\end{array}$ & $\cdot 6.64$ & 18.8 & 0 & $-3,39$ & 16.15 & 0 & -6.55 & 16.05 & 0 \\
\hline
\end{tabular}


Table 3: $-10 \%$ Variations of Nominal Values of Parameters

\begin{tabular}{|c|c|c|c|c|c|c|c|c|c|}
\hline \multirow[b]{2}{*}{$\begin{array}{l}\text { PID Tuning } \\
\text { Methods }\end{array}$} & \multicolumn{3}{|c|}{$\begin{array}{c}\text { Area-I } \\
\text { (Reheat Turbine) }\end{array}$} & \multicolumn{3}{|c|}{$\begin{array}{c}\text { Area-II } \\
\text { (Non-Reheat Turbine) }\end{array}$} & \multicolumn{3}{|c|}{$\begin{array}{c}\text { Area-III } \\
\text { (Reheat Turbine) }\end{array}$} \\
\hline & $\begin{array}{c}1^{\text {st peak }} \\
\text { over shoot } \\
\left(10^{-3}\right) \text { pu }\end{array}$ & $\begin{array}{l}\text { Settle } \\
\text { Time } \\
\text { (sec) }\end{array}$ & $\begin{array}{l}\text { Steady } \\
\text { State } \\
\text { Error(pu) }\end{array}$ & $\begin{array}{c}1^{\text {st }} \text { peak } \\
\text { over shoot } \\
\left(10^{-3}\right) \mathrm{pu}\end{array}$ & $\begin{array}{l}\text { Settle } \\
\text { Time } \\
\text { (sec) }\end{array}$ & $\begin{array}{c}\text { Steady } \\
\text { State } \\
\text { Error (pu) }\end{array}$ & $\begin{array}{c}1^{\text {st }} \text { peak } \\
\text { over shoot } \\
\left(10^{-3}\right) \mathrm{pu}\end{array}$ & $\begin{array}{l}\text { Settle } \\
\text { Time( } \\
\text { sec) }\end{array}$ & $\begin{array}{c}\text { Steady } \\
\text { State } \\
\text { Error(pu) }\end{array}$ \\
\hline No Controller & -0.05 & 33 & -0.0204 & -0.04 & 39.2 & -0.0229 & -0.05 & 34 & -0.021 \\
\hline Z-N PIR & -13 & $>100$ & 0 & -17.8 & $>100$ & 0 & -14.2 & $>100$ & \\
\hline PID Tuner & -15.3 & 11.55 & o & -26.7 & 9.4 & 0 & -14.9 & 12.5 & 0 \\
\hline $\begin{array}{l}\text { ISE } \\
\text { Optimization }\end{array}$ & -13.5 & 13.57 & 0 & -23.1 & 14.52 & 0 & -7.8 & 12.55 & 0 \\
\hline $\begin{array}{l}\text { SDO } \\
\text { Software }\end{array}$ & -6.9 & 11.55 & o & -6.7 & 8.45 & o & -7.5 & 12.3 & o \\
\hline
\end{tabular}

\section{CONCLUSION}

The decentralized PID controllers were design for three area interconnected power system with different turbines in respective areas. From the results, the Load Frequency Controller designed by Simulink Design Optimization (SDO) Software gives the effective and superior performance than other controllers for step load perturbations in all three areas. The Simulink Design Optimization Software tuned PID Load Frequency Controller is more robust then other controller for system parameter variations.

\section{APPENDIX-I:}

The nominal parameters of Reheat and Non-Reheat Turbines are collected from various Thermal power plants in India and are as shown below [9]:

\begin{tabular}{|c|c|c|c|}
\hline \multirow{2}{*}{ Parameters } & \multicolumn{3}{|c|}{ Area-i } \\
\hline & Area-I & Area-II & Area-III \\
\hline Speed Governor Time constant & $0.08 \pm 10 \%$ & $0.08 \pm 10 \%$ & $0.08 \pm 10 \%$ \\
\hline Speed Governor Regulation & $2.4 \pm 10 \%$ & $2 \pm 10 \%$ & $2.4 \pm 10 \%$ \\
\hline Power System gain constant & $120 \pm 10 \%$ & $115 \pm 10 \%$ & $120 \pm 10 \%$ \\
\hline Power System Time constant & $20 \pm 10 \%$ & $15 \pm 10 \%$ & $20 \pm 10 \%$ \\
\hline Turbine Time constant & $0.3 \pm 10 \%$ & $0.3 \pm 10 \%$ & $0.3 \pm 10 \%$ \\
\hline $\begin{array}{l}\text { Coefficient of re-heat steam turbine } \\
\text { (High Pressure) }\end{array}$ & $0.3 \pm 10 \%$ & - & $0.5 \pm 10 \%$ \\
\hline $\begin{array}{l}\text { Re-heater time constant } \\
\text { (Low Pressure) }\end{array}$ & $10 \pm 10 \%$ & - & $10 \pm 10 \%$ \\
\hline
\end{tabular}

Rated capacity $\mathrm{P}_{\mathrm{r}}=2000 \mathrm{MW} ; \mathrm{P}_{\text {tiemax }}=200 \mathrm{MW} ;\left(\delta_{1}-\delta_{2}\right)=30^{0}$ Rated frequency $\mathrm{f}^{0}=60 \mathrm{~Hz}$ and $\mathrm{D}_{\mathrm{i}}=8.33 \times 10^{-3}$; Syn. Co-efficient $\mathrm{T}_{\mathrm{ij}}=0.545$.

\section{References}

[1] Pasala Gopi and Dr. Polta Linga Reddy, "A Critical review on AGC strategies in interconnected power system," Proceedings of IET Int. Conf. on Sustainable Energy and Intelligent, Dec'13, pp 299-305.

[2] Wen Tan "Unified Tuning of PID Load Frequency Controller for Power Systems via IMC" IEEE Tran. on Power Systems, Vol. 25, No. 1, pp. 341-350, Feb 2010.

[3] Sigurd Skogestad" Simple analytic rules for model reduction and PID controller tuning" Journal of Process Control, Vol.13, pp. 291-309, 2003.

[4] S.Ohba, H.Ohnishi \& S.Iwamoto, "An Advanced LFC Design Considering Parameter Uncertainties in Power Systems," Proceedings of IEEE conf. on Power Symposium, pp. 630-635, Sep. 2007.

[5] K. P. Singh Parmar S. Majhi, D. P. Kothari,"Optimal Load Frequency Control of an Interconnected Power System" MIT Int. Journal of Electrical \& Inst. Engineering Vol.1, No.1, pp1-5, Jan 2011.

[6] P. Kundur, "Power System Stability and Control" New York: McGraw-Hill, 2003.

[7] Brian R Copeland"The Design of PID Controllers using Ziegler Nichols Tuning” IJETE, pp.1-4, Mar 2008.

[8] R. N. Patel, S. K. Sinha, R. Prasad "Design of a Robust Controller for AGC with Combined Intelligence Techniques" Journal of World Academy of Science, Engineering and Technology, pp. 687-693, 2008.

[9] Emre Ozkop, Ismail H. Altas, Adel M. Sharaf "Load Frequency Control in Four Area Power Systems Using Fuzzy Logic PI Controller" Proceedings of $16^{\text {th }}$ National Power Systems Conference, Dec-2010. 